\title{
On the Financial Support for the Development of
}

\section{National Defense Science \& Technology Industry}

\author{
Zhaozhen Fan \\ Institute of Defense Economics and Management, Central University of Finance and Economics \\ Beijing 100081, China \\ E-mail: fanzhaozhen@163.com
}

\begin{abstract}
The reform and development of national defense science \& technology industry have to depend on the powerful financial support. Emphasize on national defense science \& technology industry's financial support. Build up a stable national capital-increasing mechanism. Develop venture investments and collect venture capitals. Open more fields for investments. Follow a multiple financial way.
\end{abstract}

Keywords: Science \& technology industry, Financial support

The lagged-behind theoretical researches and practices on the national defense science \& technology industry's financial support have already restrained the reform and development of national defense science $\&$ technology industry. To strengthen theoretical researches on national defense science \& technology industry's financial support is an inevitable issue to reform and develop China's national defense science \& technology industry under the background of market economy and globalization.

\section{Financial support is an important drive for the development of national defense science \& technology industry}

Modern economic development proves that national defense science \& technology industry is a high-tech industry on one hand. On the other hand, it is a typical capital-intensive industry. The market barrier is relatively higher. Its foundation and development must have certain capital base. In China, at present in the military industry field a high-tech industrial cluster comes into being, which is an important part of China's high-tech industry. Behind the high-tech industry it is the finance that provides with support. In recent years, the financial support has already input powerful energy into the development of high-tech industry, forming a unity of science \& technology, finance, and industry. The financial support has already become the key element for the development of high-tech industry. According to Marx's theories of "the first impetus" and "the sustainable impetus", the finance, similar to science \& technology, is the first impetus for economic development. It can release great power to drive the economic development by combining with science \& technology together. Finance and science \& technology can exert unimaginable driving effect on the development of national defense science $\&$ technology industry.

Along with the establishment of social market economic system reform and the implementation of reform and open policy, the national economic environment and the operation mechanism have already experienced fundamental changes. However, so far the capitals for the development of China's national defense science $\&$ technology industry are chiefly from national financial investment. This government- dominated financial system has kind of history limits, which undoubtedly becomes a serious "bottle- neck" for the development of national defense science \& technology industry. Problems focus on three aspects. The first is the only capital resource. The national defense science $\&$ technology industry's scientific research and production capitals are chiefly from the government investment. However, the government's investment in national defense scientific research and production field is limited, which restrains the amount of capitals possessed by national defense science \& technology industry. Secondly, the investment fluctuates heavily. Government's recognition toward world situation determines the amount of investment to a great degree. An optimistic recognition will bring about a sharp decrease of investment in national defense science \& technology industry, and a pessimistic recognition a fast increase. The big fluctuation conflicts with the stable development of national defense science \& technology industry. The third is the uncertainty of capital resource, what will affect enterprises' expectation for the future and restrains its long-term development.

Entering the 21 st century, most influencing countries in the world expedite their investment in national defense scientific research. The proportion of national defense scientific research expense to the total national defense expense tends to increasing annually. Every country puts the development of high-tech weapons and equipments at a primary position. According to data in China national defense white paper, the proportion of China's investment in national 
defense scientific research is merely about one second or one third of developed countries'. Even with the limited investment in national defense, most are used for the maintenance of common equipments, and less for new scientific research. Apparently, as a kind of special public goods, national defense science \& technology industry needs government's investment. Especially for the high-tech national defense field that is impossible to be commercialized, the government must guarantee its investment. However, the government investment is far from sufficient in order to achieve the modernization of national defense science $\&$ technology industry and its leading trend. Modern financial system should provide with material support for the national defense science \& technology industry. Therefore, it is necessary to construct a modern financial system in which the government financial investment provides with directives, the private investment is the main body, the foreign investment is the assistance, and the policy financial investment is the complement. This financial system can support the development of national defense science \& technology industry by exploring new capital resources for the national defense science $\&$ technology industry.

\section{The directions and emphases of financial support for the development of national defense science \& technology industry}

In the strategic aspect, the emphases of financial support for the development of modern national defense science \& technology industry should include:

The first is the core industry, or the military equipment. This industry focuses on the research, production, and marketing of weapon equipment, including nuke, military planets, spaceflight carriers, military planes, naval vessels, army weapons, and military electrics, what is the foundation of national defense science \& technology industry.

The second is the dominant industry that has prominent military features and is controlled by the Commission of Science Technology and Industry for National Defense. It includes five branches, namely civil use of nuclear energy, civil spaceflight, civil planes, civil ships, and civil explosive materials. These five branches have priorities in the development of national defense science \& technology industry, what can drive the development of national economy. According to the history of industrial development in industrialized countries, military branches can significantly drive the industrial upgrade of national economy. In some developed countries, civil use of nuclear energy, civil spaceflight, civil plane industry, civil ship industry, and electric and information industry have already become the backbone and dominant industries. For these industries, although it is relatively easier to make best use of the market finance and the private investment under the condition of market economy, the government does exert its positive effect on the financial support for the national defense's high-tech dominant industry. Especially under the background of imperfect financial market and limited private capitals in China, the government should enhance its support for the national defense's high-tech dominant industry instead of decreasing its investment.

The third is the superior civil product industry. Because of the transformation from military production to civil production, products in this industry usually occupy significant market shares in other industries of the national economy, including automobiles, motors and parts, photoelectric information products, environmental protection products, machines and equipments, new materials, medicines and medical equipments. For this industry, the proper way is to combine military production with civil production and adopt the modern property right system, taking the market need as the directive, the industrialization as the goal, the commercialized operation as the way, turning the mature technologies used in military field and civil field into commercialization, industrialization, and marketization, speeding up the development of civil products. Along with the transfer of advanced civil technologies to civil uses, financial institutions should not only provide with stable and sustainable capitals for scientific research, but also allocate capitals property, making up different strategies for different industries in capital uses, exerting the general function of bank capitals completely. Only by this way, can financial institutions exert their effects as the modern economic core, realizing the lever function of driving the development of national defense's superior civil product industry.

\section{Suggestions for countermeasures to enhance financial support}

For a long time, the national defense science \& technology industry is controlled by the state. The national finance investment and banks' special credit loans constitute the main capital resources of national defense science \& technology industry. The only investment subject can not provide with powerful financial support for the development of national defense science \& technology industry. Therefore, we should meet the requirements of reform and open policy and the trend of economic globalization. Open the investment fields of national defense science \& technology industry. Attract sorts of social capitals widely, including foreign capitals. It is a must to constitute a multiple investment structure for the development of national defense science \& technology industry.

Firstly, build up a stable national capital-increasing mechanism. The first is to set up a "proper proportion" of government investment for the construction of national defense science \& technology industry. The "proper proportion" can guarantee the increase of expenses in national defense science \& technology industry along with the increase of national economy. The government should increase its financial investment in the national defense science \& technology industry properly, which can guarantee its sustainable development to a great degree. According to the law 
of world development and the successful experiences of other countries, and taking sorts of factors into consideration, the "proper proportion" should be lightly larger than practical needs with the precondition of ensuring national safety. The second is to build up long-term relationship with credit banks. Obtain middle or long-term low-interest loans. Develop capital market. Set up scientific research fund. Increase the proportion of science \& technology loans. Create venture investment firms. Take best use of foreign capitals and increase capital investment. The third is the state's indirect adjustment and control. Use economic lever and economic policy directives to guide financial institutions' investment amounts and structure, driving the structural adjustment of national defense industry. Under present condition of tight financial capitals, the government should encourage banks to provide with loans for the national defense science $\&$ technology industry as much as possible. The fourth is to emphasize on the guidance and openness of national defense science \& technology industry's development program in order to guide the social investment activities.

Secondly, develop venture investment and collect venture capitals. Encourage all investment subjects at home and abroad to set up venture investment institutions, venture investment companies, and venture investment management firms. At present, there are 800-1200 venture investment firms in western countries. The total capitals are about 12-16 billion dollars or so. Venture investment is also named as "partners of high-tech exploration", "motives of the fourth industrial revolution", and "investment for the future". It has already become a guiding support for high-tech enterprises and an important complement for high-tech capital extension. Facts prove that combining new innovations, new inventions, and venture capitals is a practical way to develop high technology. Although 80 percent of venture investment may fail at last, it is a powerful way to achieve high-tech product research \& development. Among few successful cases, people not only take back all investments, but also obtain enormous and great social economic benefits. Any other investments can not realize this effect. According to practices at home and abroad, this investment organization and operation can integrate venture capitals, investment institutions, and high-tech enterprises properly, realizing a rational allocation of investment risks and profits in all investment subjects. By this way, it can provide with powerful support for the development of high-tech industry. The national defense science $\&$ technology industry should explore the mode of constructing a normal venture investment organization. The first is to make institutions become the controlling shareholders of venture investment organization. Institutions, as investors, have large amounts of capitals, rich human resources, and advanced management methods. Besides, the property right system and governance structure are in accord with the rules of market economy. Institutions holding most shares and participating into the decision and management can help venture investment organizations to exert their supposed effects completely. The second is to regulate venture investment organizations' behaviors. Venture investment organizations should be independent economic bodies. Their operations are based on the law of market economy and international principles. They participate into the capital finance and market competition with fairness and justness. They should not disobey laws and regulations, or hurt the interests of investors and the right of competitors in purpose. The third is to make up relevant policies, laws, taxes, and conditions for loans. By this way, the government can drive the construction of venture investment companies. To perfect the legal system for the financial support of the national defense science $\&$ technology industry should begin with the transformation of venture investment subjects. Define the legal forms of venture investment subjects clearly and protect the property right of founders undoubtedly.

Thirdly, open the investment fields of national defense science \& technology industry and follow a multiple financial way. The first is to make full use of capital market and develop direct financial completely. Encourage high-tech enterprises to list in main board market and growth enterprises market and achieve finance in capital security market. Enlarge the stock size of listed companies and improve their profitability. Guide listed companies to finance from key projects. Encourage superior industry enterprises to purchase and merge listed companies, strengthen capital operations, and achieve a fast extension in virtue of capital market. The second is to attract private capitals. Create a favorable environment for private capitals entering the national defense science \& technology industry. Encourage and guide private capitals, especially carve-out (venture) investment funds at home and abroad, to participate into the exploration of national defense science $\&$ technology industry and the reform of traditional industry. The third is to improve the size, quality, and effect of foreign capitals in this field. China is still at the socialism initial stage. The social resources available for national defense science \& technology industry are far less than practical needs in quality and quantity. To introduce and use foreign resources can effectively make up this shortage. Therefore, it is necessary to make use of foreign capitals. With precondition of obeying the principle of protecting secrecies, the national defense science \& technology industry can open some fields, such as these enterprises that produce common military equipment products or do not produce military products any more, to certain degree. Foreign capitals can enter the military and civil high-tech industries that open to the society by means of joint venture, cooperation, stock system, and participation into venture investment.

\section{References}

Li, Qingshan. (1995). New Military Reform and High-Tech War. Beijing: Military Science Publishing House. 
Ren, Haiping. (2004). From military production to civil production: the new development trend of world war industry. National Defense Science \& Technology. April.

The work team of a subject on Zemin Jiang's national defense science \& technology construction thoughts. (2005). Study on Zemin Jiang's National defense Science \& Technology Construction Thoughts. Beijing: Publishing House of Electronics Industry.

Yu, Aishui. (2005). Interaction between Military Affairs and Economics. Beijing: China Economy Publishing House. 